\section{CRIPTOSPORIDIOSE HUMANA}

Até recentemente, a infeç̧ão humana pelo Cryptosporidium, era uma curiosidade na literatura médica, ocorrendo geralmente como uma infecção oportunista em pacientes com imunodepressão. ${ }^{10}$ A sindrome da imunodeficiência adquirida (SIDA)' tem sido relatada em muitos casos e apenas um só autor reuniu em Nova lorque 25 pacientes homossexuais com esta infecção ${ }^{3}$. Este número é o dobro do atualmente encontrado na literatura (PMa: comunicação pessoal) $A$ infecção em imunodeprimidos leva a uma síndrome de malabsorção, persistente e debilitante, que pode ser fatal. Não existe, até o momento, terapêutica eficaz para o tratamento desta sindrome. ${ }^{5}$

O gênero Cryptosporidium faz os ciclos de multiplicação sexuado e assexuado, nas células epiteliais do trato gastrintestinal. Os oocistos aparecem nas fezes com quatro esporozoitos expostos e nenhuma parede no esporocisto.

A criptosporidiose é bem conhecida dos veterinários como causa de diarréia em vacas, podendo a sua transmissão ao homem ocorrer através destes animais.? A especificidade do hospedeiro, tal como acontece com o gênero Eimeria, não é um achado do Cryptosporidium ${ }^{8} \mathrm{e}$, até o momento, não está claro a especificação do gênero. ${ }^{3}$

O primeiro relato da infecção humana pelo Cryptosporidium foi em 1976, em uma paciente com boa resposta imune e que se curou espontaneamente. Desde então, outros casos continuam a ser registrados. ${ }^{2}$ Não se sabe até quando a diarréia transitória em indivíduos imunocompetentes é devida à criptosporidiose, mas o teste sorológico sugere ser este organismo grandemente distribuido entre os mamíferos."

Até há um ano, o diagnóstico de certeza no homem dependia do achado em material de biopsias, de formas minúsculas, desenvolvendo-se na borda em escova do epitélio colunar do intestino delgado. ${ }^{10}$

Usando-se a técnica de flutuação das fezes em soluçào de açúcar saturada, podem ser vistos os pequenos oocistos com 4 a 5 micra, corados em rosa. Uma coloração ácido resistente pode ser usada para uma montagem permanente. ${ }^{4}$

\section{HUMAN CRYPTOSPORIDIOSIS}

Cryptosporidial infections of man were a medical curiosity in the literature until recently; occurring usually as an opportunistic infection in immunosuppressed patients ${ }^{10}$.

The acquired immunodeficiency syndrome (AIDS) ${ }^{1}$ has resulted in many cases and one worker alone in New York City has collected 25 homosexual patients with this infection, twice the number currently recorded in the literature (PMa: personal communication). In immunosuppressed patients infection results in a persistent, debilitating malabsorption syndrome which may be fatal. There is no effective therapy. ${ }^{5}$.

The genus Cryptosporidium has sexual and asexual cycles of multiplication in the epithelial cells of the gastrointestinal tract. Oocysts with four naked sporozooites and no evident sporocyst wall appear in the stool. Cryptosporidiosis is well known to veterinarians as a cause of diarrhoea in calves and transmission has occurred to man from these animals. ${ }^{7}$ Host specificity, such as occurs in the genus Eimeria, is not a feature of cryptosporidium $^{8}$ and speciation of the genus ${ }^{3}$ is unclear at the present time.

The first report of human cryptosporidial infection in 1976 was in a patient with an intact immune response who recovered spontaneously and such cases continue to be reported. ${ }^{2}$ How often transient diarrhoea in immunocompetent individuals is due to cryptosporidiosis is unknown, but serological testing suggests that the organism is widely distributed in mammalian hosts. ${ }^{9}$.

Up to a year ago firm diagnosis in man depended on finding the tiny developing forms in the brush border of the columnar epithelium in small bowel biopsies.' However stool flotation in saturated sucrose solution reveals the tiny $4-5$ micronsoocyst ${ }^{8}$ which has a pink colour using this technique. An acid fast stain can be used to make a permanent mount. ${ }^{4}$. 
A pesquisa de Cryptosporidium em pacientesimunossuprimidos com diarréia e em vacas, em diferentes partes do mundo, poderá mostrar resultados interessantes. Assim, este parasito deve ser considerado o mais importante dos três gêneros de coccídeos intestinais humanos, denominados Cryptosporidium, Isospora e Sarcocystis.
A search for cryptosporidia in immunosupressed patients with diarrhoea and in calves in different parts of the world should yield interesting results. Already this parasite must be considered the most important of the three genera of human intestinal coccidia namely Cryptosporidium, Isospora, and Sarcocystis.

\section{REFERENCIAS BIBLIOGRÅFICAS}

1. Acquired immunodeficiency syndromes. Lancet Jan. 22 1: 162-164, 1983

2. Babb RR, Differding JI, Trollope MI. Cryptosporidia enteritis in a healthy professional athlete. American Journal of Gastroenterology 77: 833-834, 1982

3. Levine ND. Some corrections of Coccidian (Apicomplexa, Protozoa) nomenclature. Journal of Parasitology 66: 830-834, 1980

4. Ma P, Soave R. Three-step stool examination for cryptosporidiosis in 10 homosexual men with protracted watery diarrhoea. The Journal of Infectious Diseases 5: 824-828, 1983

5. Marsden PD. Human intestinal coccidiosis. Microbiology Reviews (in press)

6. Nime FA, Barek JD, Page DL. Acute enterocolitis in a human being infected with the protozoan Cryptosporidium. Gastroenterology 70: 592-598, 1976
7. Rees NC, Current WL, Ernst JV, Bailey WS. Cryptosporidiosis of man and calf. A case report and results of experimental infections in mice and rats. American Journal of Tropical Medicine and Hygiene 31: 226-229, 1982

8. Tzipori S, Angus KW, Campbell I, Gray EW. Cryptosporidium: evidence for a single species genus. Infection and Immunity 30: 884-886, 1980

9. Tzipori S, Campbell I. Prevalence of Cryptosporidium antibodies in ten species of animals. Journal of Clinical Microbiology 14: 455-456, 1981

10. Weinstein L, Edelstein SM, Madara JL, Falchuck KR, McManus BM, Trier JS. Intestinal Cryptosporidiosis complicated by disseminated cytomegalovirus infection. Gastroenterology 81: 584-591, 1981.

Philip Davis Marsden

Núcleo de Medicina Tropical e Nutrição

Universidade de Brasília 